\title{
Kumis treatment in the steppe regions as a promising direction of tourist nature management
}

\author{
Natalia Sviatokha ${ }^{1, *}$ and Irina Filimonova ${ }^{2}$ \\ ${ }^{1}$ Orenburg State University, 13, Prospect Pobedy, 460018, Orenburg, Russia \\ ${ }^{2}$ The Institute of the Steppe of the Ural Branch of the Russian Academy of Sciences, 11, Pionerskaya \\ str., 460000, Orenburg, Russia
}

\begin{abstract}
Recently, much attention has been paid by scientists from different countries to the issues of tourist environmental management. The kumis therapy development, being a historically established direction of medical tourism, is promising in the steppe regions. When analyzing the history of the development of kumis therapy in the former USSR, it was revealed that after the collapse of the USSR, an organized network of kumis treatment centers ceased to exist. Original maps reflect historical aspects and modern geography of sanatorium with kumis treatment. Most of them are located in the forest-steppe and steppe zones. The paper considers the steppe region of Russia - the Orenburg region promising for the development of kumis treatment in connection with a suitable dry steppe climate, the development of horse breeding and the possibilities of landscape therapy. The paper notes the appropriateness of the further development of kumis treatment and the modernization of kumis treatment centers in the Orenburg region.
\end{abstract}

\section{Introduction}

Recently, the consumption of kumis in food is considered the European trend in healthy eating. It is believed that kumis began to be used in Europe more than 40 years ago due to the emergence of the dairy farm in Germany (Waldbrunn, Odenwald district). Now it is considered one of the largest in Europe ( 400 horses). It was founded by a German veterinarian, who gained experience in organizing kumis treatment in the USSR, where he lived for 8 years. In addition to the drink, kumis powder and cosmetic products based on kumis are produced at its horse farm. Today in Germany there are about 40 dairy farms [12].

Later, the production of kumis was developed in other European countries: Belgium (about 40 dairy farms), France, (30 dairy farms), Austria, Spain, the Netherlands, Italy. Despite the popularity of this drink, there are no kumis medical clinics in Europe. Kumis treatment opens up new perspectives for the development of tourism on family farms, increases farm diversification into tourism [3].

\footnotetext{
*Corresponding author: osugeo@yandex.ru
} 
This is understandable, since it is advisable to locate the kumis medical clinics in arid steppe regions [4-5] favorable for the treatment of respiratory organs. That is why we will take a closer look at the steppe region - the Orenburg region - which in the past attracted many visitors from Europe to the health resorts with kumis.

Nowadays one of the priority targets for regional development in Russia is creation of a system for rational natural resources management and optimization of its geographical coverage [6]. The main features of rational natural resources management are: recognition of stable development principles, integrated and effective use of natural-resources potential of the territory, coordination of management and local inhabitant interests, preservation of favorable ecological situation. To our mind one of the tasks of the regional tourist policy in the steppe areas of Russia, and in the Orenburg region in particular should be stable development of the tourist-recreational sphere, and that to wide extent would promote rational management of natural resources.

It is important to point out that recently the interest of public authorities for tourist potential and recreation resources of the region is growing in Russia and in the Orenburg region [7], as it is the most able-to-get opportunity from economic point of view for satisfaction growing recreation needs of the population. In this regard there is a necessity for scientifically based approach to recreation management of natural resources development in the Orenburg region, and the kumis therapy is an upcoming trend.

By recreation resources we mean natural, natural-technical and social-economical geosystems and their elements, which under existing engineering and financial capabilities could be used for recreation economy organization. Substantial contribution in formation the idea of recreational resources has been made by V.S. Preobrazhensky, L.A. Bagrova, Yu.A. Vedenin, Winter P.L. etc [8]. Recreational resources are dived into: climatic, hydromineral, water, forest, mountain and resources of seaside.

The Orenburg region possesses a great recreational potential for development of all kinds of recreation and tourism [9-10].

A great value for studying the Orenburg recreational resources present research works of natural scientists: P.I. Rychkov, E.A. Ewersmann, P.S. Pallas, S.S. Neustruev, N.A. Zarudny etc. In their works was marked the availability of favorable natural-climatic resources in the region, promoting integrated development of traditional (historical) for the area kind of health improvement - the kumis therapy. In 1770 P.S. Pallas wrote in his notes: "To Bashkir steppe arrived sick people from Moscovia and the Don to drink kumis, because the last posses a great use by itself for health". The famous Russian writer S.T. Aksakov, who observed Bashkir-nomad way of life also noted health-giving role of kumis. In his letters related to 1781, S.T. Aksakov wrote: "In spring as soon as the chernozem steppe got covered with fresh, aromatic, lush vegetation, and fillies, malnourished in winter time, stored fat, in all sheds starts production of kumis. And everybody who can drink from a babe in arms to a gummer do drink that balmy, fruitful, herculean product...".

\section{Materials and Methods}

The main methods for investigation became: historical-geographical, comparativegeographical, cartographic, statistical, field studies.

It is believed that kumis medical hospitals, that are located in the steppe zone, has a particular value, because they are combining the healing properties of the arid steppe climate and a fermented milk drink (climate and kumis treatment) [5]. This explains the authors' choice of the study area - the steppe region, in particular, the Orenburg region. Horse breeding, as well as the production of kumis and horsemeat was some of the traditional forms of farming of the nomadic peoples of the Orenburg steppes. Nowadays, kumis treatment is indicated for many forms of tuberculosis, as well as for other respiratory diseases [11-12]. 
Kumis has a beneficial effect on the central and autonomic nervous system, on the general condition of the body. In connection with the centuries-old traditions of the development of kumis treatment in the steppe zone of Eurasia, it is necessary to analyze the history of the development of kumis treatment on the basis of medical institutions in Russia.

\section{Results}

The world's first kumis medical clinic was opened in 1854 in the village Bogdanovka of the Samara province. A few years later, several kumis treatment centers appeared in the Samara, Ufa and Orenburg provinces. Very soon kumis therapy became very popular. Up to 1858 a number of patients, coming to take kumis therapy were calculated in tens in the three before mentioned governments, in 1912 it reached approximately 10000 patients, there were 40 specialized kumis therapy medical centers and about 75 rural settlements where kumis drinkers came. By the beginning of the XX century there were more than sixty kumis therapy medical centers in Russia. There were also kumis centers of local significance, where breeders independently produced and sold kumis. Some kumis drinkers lived in nomads tents (yourt) in the vicinity of pastures inhabited by milch mares [13].

According to Decree of Sovnarkom of RSFSR from 27 January 1926 «On Amendments to the list of national importance resorts» in 1926 in the USSR were pointed out 4 kumis therapy regions, having federal significance: Shafranovsky, Orenburgky, Buzuluksky, Borovoe (figure 1).

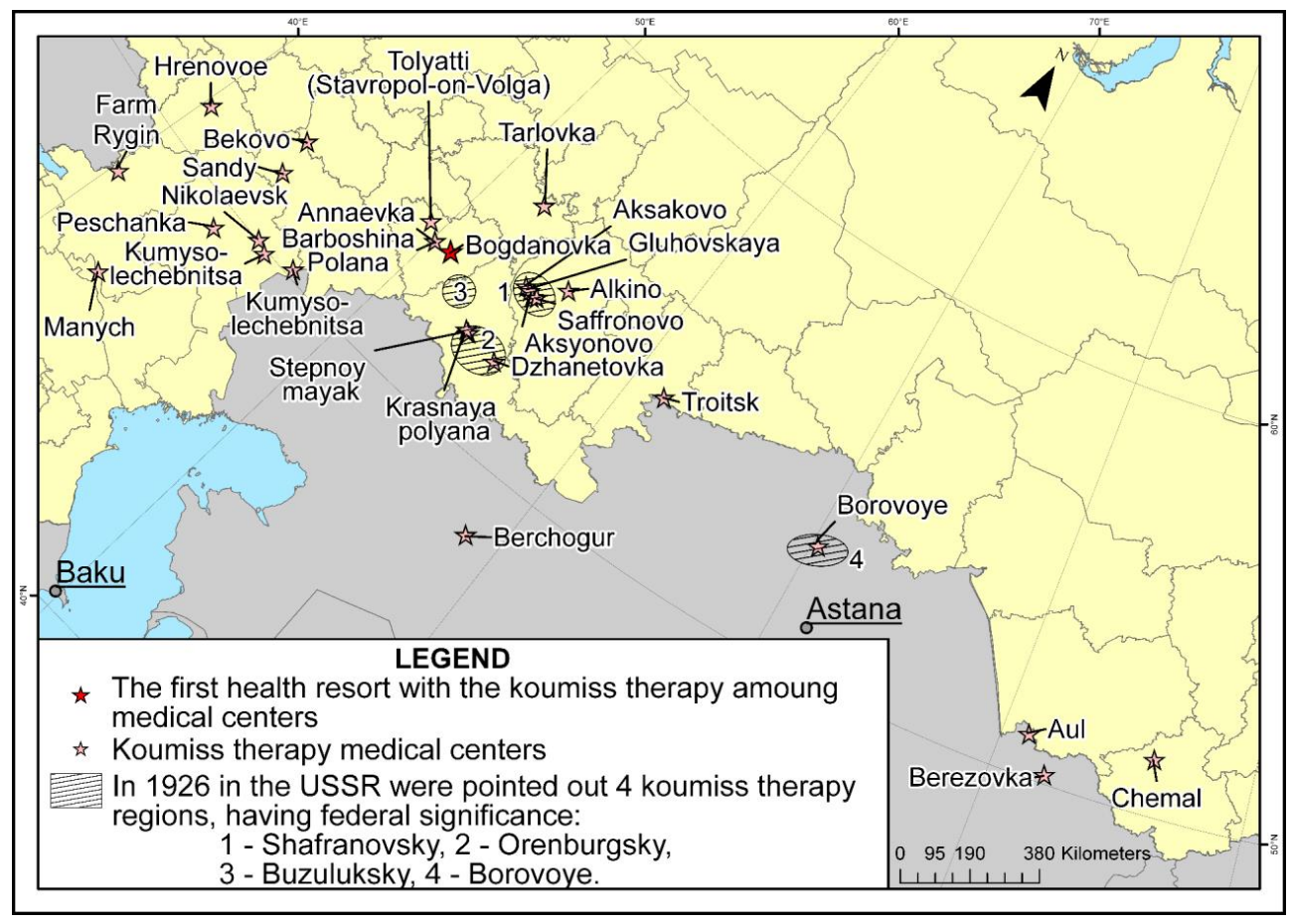

Fig. 1. Areas of kumis therapy and kumis therapy medical centers in the USSR.

The other kumis therapy medical centers had local significance. All existing in the USSR kumis therapy medical centers were split into two categories: the first one included specialized kumis therapy medical centers in the steppe area, to the second - related medical centers, where kumis was used as an additional remedy. 
Rural kumis therapy has been also spread. Especially in Bashkiria, in the river Djoma valley, along the Samaro-Zlatoustovsky railway, in the Orenburg region - along the Tashkent railway (villages Zubochistka, Blagoslovenka, Perevolotsk and others) there were a lot of communities occupied with kumis business.

The organized net of medical centers practicing kumis therapy stopped its existence with the decay of the USSR. However, in recent time the tendency for a new birth of kumis medical centers is observed. Their number in the world is not great - about 40 , but half of them are located in Russia (figure 2).

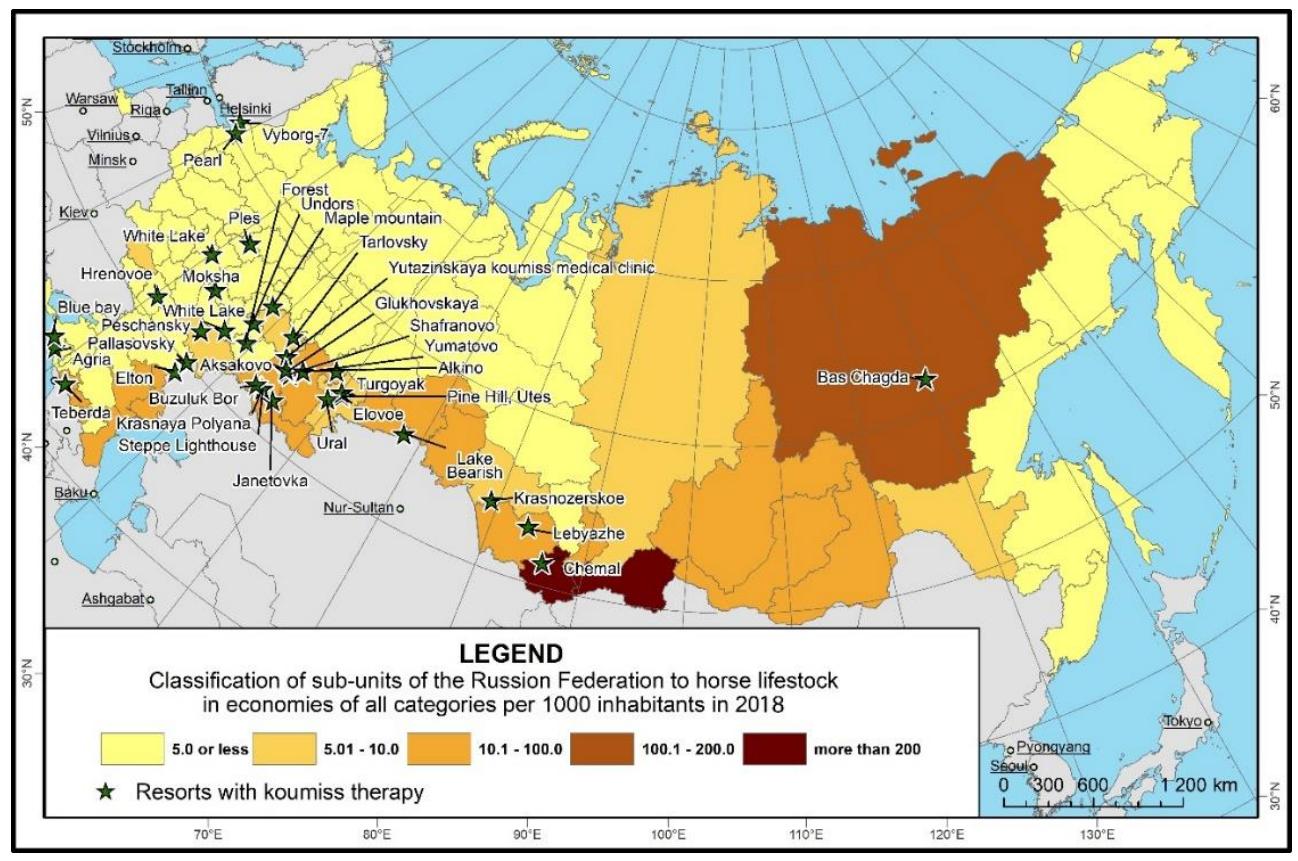

Fig. 2. Classification of sub-units of the Russian Federation to horse livestock in economies of all categories per 1000 of inhabitants in 2018. Compiled by authors to [14].

After the collapse of the USSR, the number of horses in the country sharply decreased (by almost $50 \%$ ), only 15 years later there was a tendency for a gradual increase in their number. In 2018, in Russia, the absolute leaders in the total horse population are the Republic of Sakha (Yakutia), the Republic of Bashkortostan and the Republic of Altai. As of the beginning of 2020, the pedigree livestock breeding base includes: 216 organizations engaged in breeding horse breeding, 69 pedigree stud farms and 36 hippodromes [15].

\section{Discussion}

At present, kumis is produced in several regions of Russia. In the production of kumis, the Volga Federal District has been a leader for many years (Figure 3). Volga Federal District annually produces over $50 \%$ of the total volume of kumis in the country [14]. 


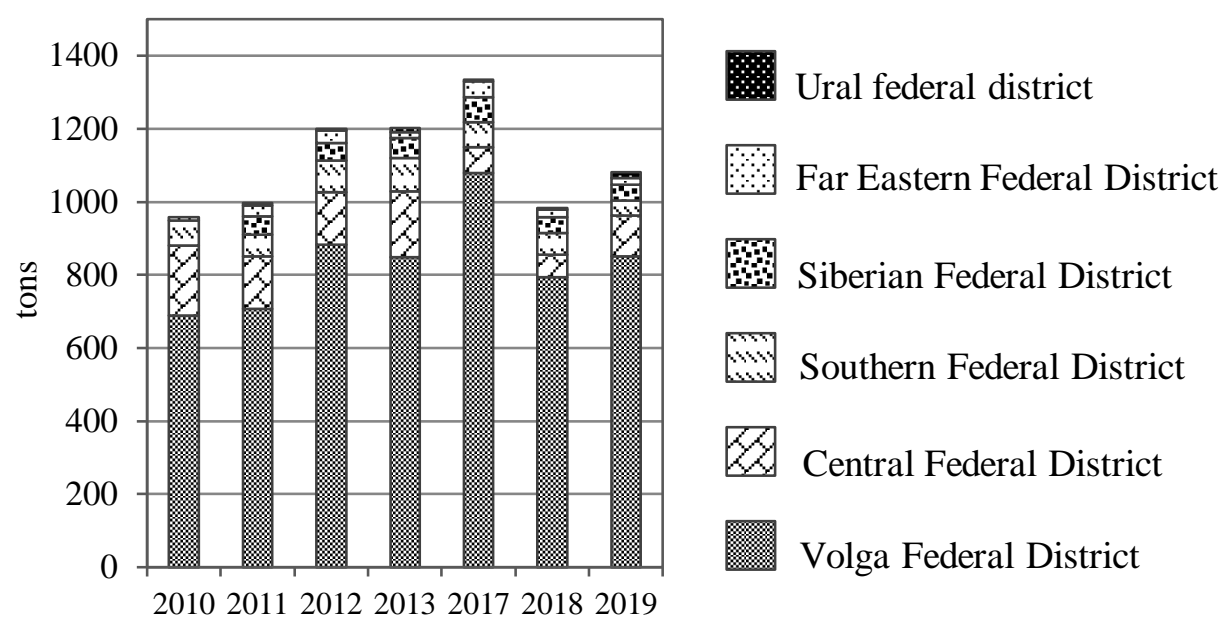

Fig. 3. Production of kumis by volume in federal districts of the Russian Federation since 2010. Compiled by authors to [14].

Many scholars talk about the need to revive the network of sanatorium with kumis treatment and horse breeding in the steppe zone - in particular in the Orenburg region. This is confirmed by the work of researchers [4-9-16].

According to statistics, in 2019 the incidence of tuberculosis in the Orenburg region was $22 \%$ higher than the average for Russia (The federal state statistics service, 2020). It is important to note that today in the Orenburg region kumis is used to treat tuberculosis only in two areas of the region: Sakmarsky (summer recreation camp "Dzhanetovka") and the Novosergeevsky (sanatoriums "Stepnoy mayak" and "Krasnaya polyana") districts.

As wrote Orenburg researcher T. Bolshakova "Dzhanetovka" sanatorium with kumis treatment was the first category health resort among the kumis therapy medical centers of the Samara and Orenburg govemments. It was founded on the river Yangiz in 1882 by the englishman doctor J.L. Carrick and named after his nice Janette. To study the experience the doctor inspected all kumis therapy medical centers in the Samara government, he made three trips to the Turgaysky region of Kazakhstan to study keeping of mares and procedures of kumis production by the Kazakhs and the Kirghiz. The advantage of "Dzhanetovka" over the most beautiful kumis therapy areas of the Ufa government was in splendid dryness of air and absence of dew, and that was very important for tuberculosis sick patients. The kumis therapy medical centers became famous abroad after participation of J.L. Carrick in the London International Exhibition (1884). The ethnographical display presented by J.L. Carrick at the exhibition got acquainted the Englishmen with customs and way of life of the Kazakhs, the Kirghiz, the Tatars, the Bashkirs. The visitors were offered kumis in unlimited quantity. That was a success. Princess Beatrix bought a mare with a foal, many artists captured in their works people's way of live, presented in the ethnographical display. By the end of the exhibition all the everyday items were sold. Healing properties of steppe landscapes and kumis attracted Russian and foreign patients to Dzhanetovka.

The place where "Stepnoy mayak" sanatorium is located in present time was called "Tsarsky dar (Tsar's gift)" before. Up to 1919 the sanatorium was a private kumis therapy medical center, later it got the status of the All-Union center, and was expanded to 325 beds. In present time, the kumis therapy seasonal anti-tuberculosis sanatorium "Stepnoy mayak" is rated for 250 beds. The sanatorium "Krasnaya polyana" was built in 1903 by the merchant Sukhovilov that was a private kumis therapy medical center. With the establishment of the 
Soviet Power it was nationalized, it had status of an All-Union health center. Nowadays the sanatorium is rated to 250 beds.

\section{Conclusions}

In such a way, kumis therapy as a trend of health-related recreational management of natural resources has a long history of start-up and development at the territory of Russia. The importance of kumis therapy revival and modernization of kumis therapy medical centers net was marked by the authorities at the regional level.

The Orenburg region is perspective for kumis therapy development, it is possible to mark the following districts: Kuvandyksky, Saratashsky, Belyaevsky, Pervomaysky, Sol-Iletsky, Akbulaksky. Besides kumis therapy is possible to combine with hippotherapy - healing horse riding and rural tourism.

In development regional policy programs of the Orenburg region in the field of tourism and recreation, it is necessary to pay special attention to kumis therapy, since the region has all the necessary competitive advantages for development of the given kind of recreational management of natural resources: steppe climate, unique opportunities of landscape therapy, phytoncids properties of steppe vegetation and horse breeding as a traditional form of economic management. Effective and rational use of recreational resources of the territory also effects directly on creation of tourist-recreational attractiveness and image of the Orenburg region.

This work was carried out as part of the state assignment "Steppes of Russia: landscapeecological foundations of sustainable development, substantiation of nature-like technologies in conditions of natural and anthropogenic environmental changes" (AAAA-A17117012610022-5).

\section{References}

1. H. Nurtazin, S. Ishii, Eurasian Journal of Ecology 42, 123-131 (2016)

2. M. Doreau, W. Martin-Rosset, Encycl. Dairy Sci. Second Ed., 358-364 (2011) https://doi.org/10.1016/B978-0-12-374407-4.00040-6

3. B. Brandth, M.S. Haugen, Journal of Rural Studies 27, 35-44 (2011) https://doi.org/10.1016/j.jrurstud.2010.09.002

4. A.A. Chibilev, Geography and Natural Resources 30, 219-223 (2009) https://doi.org/10.1016/j.gnr.2009.09.003

5. S.I. Shii, B.H. Osino, H.K. Omiyama, A.U. Ehara, S.N. Urtazin, Study on Production and Properties of Kumiss of Herders in Mongolian Dry Steppe 197, 195-197 (2014)

6. A. Hardy, L.J. Pearson, Journal of Destination Marketing and Management 8, 247-258 (2018) https://doi.org/10.1016/j.jdmm.2017.05.001

7. L. Andrades, F. Dimanche, Tourism Management 62, 360-376 (2017) https://doi.org/10.1016/j.tourman.2017.05.008

8. P.L. Winter, S. Selin, L. Cerveny, K. Bricker, Sustainability (Switzerland) 12, 1-12 (2020) https://doi.org/10.3390/SU12010081

9. Z. Ermakova, I. Polyakova, Y. Kholodilina, The Case of the Orenburg Region, 217-221 (2020) https://doi.org/10.2991/assehr.k.200113.044

10. K. Dashper, Tourism Management Perspectives 34, 100678 (2020) https://doi.org/10.1016/j.tmp.2020.100678

11. Q. Hou, C. Li, Y. Liu, W. Li, Y. Chen, Siqinbateer, Y. Bao, W. Saqila, H. Zhang, B. 
Menghe, Z. Sun, Journal of Functional Foods 52, 469-478 (2019) https://doi.org/10.1016/j.jff.2018.11.023

12. D. Lucena-Antón, I. Rosety-Rodríguez, J.A. Moral-Munoz, Complementary Therapies in Clinical Practice 31, 188-192 (2018) https://doi.org/10.1016/j.ctcp.2018.02.013

13. T. Uniacke-Lowe, T. Huppertz, P.F. Fox, International Dairy Journal 20, 609-629 (2010) https://doi.org/10.1016/j.idairyj.2010.02.007

14. Federal state statistics service, https://www.gks.ru/

15. Ministry of Agriculture of the Russian Federation. (n.d.). http://mcx.ru/en/

16. S. Kirillov, S. Kanischev, A. Kholodenko, D. Solodovnikov, 14th GeoConference on ecology, economics, education and legislation, SGEM2014 Conference Proceedings 2 , 251-258 (2014) https://doi.org/10.5593/SGEM2014/B52/S20.034 